\title{
The 2008 Global Financial Crisis and The Liquidity Management of The Central Bank of The Republic of Turkey
}

\author{
Nadir Eroğlu \\ Department of Economics, Marmara University \\ Ressam Namık İsmail Sok. No.1. 34590 Bahcelievler/ISTANBUL-TURKEY \\ Tel: 90-212-507-9925 fax: 90-212-505-9332 E-mail: neroglu@marmara.edu.tr \\ İlhan Eroğlu \\ Department of Economics, Gaziosmanpaşa University,60240/ TOKAT- TURKEY \\ Tel: 90-356-252-1616 Fax: 90-356-252-1673 E-mail: ieroglu@gop.edu.tr
}

Received: August 23, 2010

Accepted: September 23, 2010

doi:10.5539/ijef.v3n2p186

\begin{abstract}
The most typical feature of financial crises is that the money demand of almost all economic units increases and they wish to keep their properties as cash that is the most liquid asset. This is caused by the loss of confidence between economic units. In the 2008 Financial Crisis, this feature has come into prominence and a shortage of liquidity and credit that affected all countries has appeared. Avoiding the negative effects of the financial crisis is only possible through a good liquidity management. Central banks of the USA, Europe and other developed and developing countries have taken several measures in order to solve the shortage of liquidity. The Central Bank of the Republic of Turkey (CBRT) has also made some regulations in the financial crisis. The aim of this study is to investigate the essential dynamics of the 2008 Financial Crisis and evaluate the liquidity management that the CBRT has followed against the financial crisis.
\end{abstract}

Keywords: Financial Crisis, Liquidity Management, Monetary Policy Strategy

\section{Introduction}

Until the global financial crisis erupted in September 2008, the most important problem faced by world economies was seen as high inflation. With the signs of slowdown in the world economy in 2000, central banks of the USA, Europe and Japan started to decrease interest rates by implementing loose monetary policies. This increased banks' tendency to borrow short-term at low interest rates and lend long-term, due to the ample liquidity in financial markets. In this period, because of the ample liquidity in the world, increased food, commodity and energy prices against high aggregate demand were the essential dynamics that fed inflation. However, in September 2008, it was realized that the primary problem was not high inflation but deflation, recession and credit contraction, which were bitterly felt by all countries and followed by macroeconomic problems. Especially the bankruptcy of Lehman Brothers showed the seriousness of the crisis. All countries, all sectors and all firms throughout the world have experienced the severity of the crisis in a little while. Even though Turkey entered into the 2008 crisis with the experience of the crisis occurred in 2001, which might be considered "our own crisis", she could not escape the negative and catching effects of crisis.

The problem of high inflation, which had been seen as the primary problem until the 2008 Crisis, was considered to be a distinctive feature between developed and developing countries. Countries with high dependence on foreign energy sources were not strong enough to resist the process of inflation caused by increasing energy prices. In this respect, since the crisis affected all countries, the distinctive feature of the 2008 Global Crisis is that it divided countries into two groups; those who are able to take the necessary measures against the crisis and those who are not, rather than the developed-underdeveloped distinction. The phenomenon of financial liberalization that became widespread after 1980 played an important role in the nature of the 2008 Financial Crisis. The international financial system has become a very complex structure with the dynamism brought about by globalization in early 2000s. In this respect, it was not possible for any open economy where the movement of capital is free to stay out of the crisis regardless of the country and the economic policy she pursues. The problems in the housing market in the USA spread into the entire financial system and increased all countries' perceptions of risk by destabilizing their economies. Against the global crisis, which first appeared in the housing market in the USA and eventually became a crisis of liquidity, the Federal Reserve System (FED) took several measures in its liquidity management but was not able to prevent the crisis from spreading to other financial institutions and countries. In parallel with this, many developed countries adopted nonconventional 
methods in liquidity management in order to reduce the effects of the crisis. In developing countries including Turkey, on the other hand, the International Monetary Fund (IMF) took initiative to solve these countries' temporary liquidity problems by considering the level of risks they carried. The measures taken based on the shortage of liquidity partially succeeded.

The monetary policy strategy and the liquidity management that the Central Bank of the Republic of Turkey (CBRT) pursued in this period in which Turkey did not make any agreement with the IMF became more successful -with the contribution of the strong infrastructure of the banking sector- in limiting the effects of the crisis, compared to other countries. The aim of this study is, within the perspective of the 2008 Global Financial Crisis, to evaluate the liquidity management that the CBRT pursued against the liquidity and -thus- credit shortage, and its macroeconomic consequences. The study will firstly present the reasons of the 2008 Global Financial Crisis. Then, current monetary policy strategies against the global crisis will be evaluated, and finally the liquidity management that the CBRT pursued in the crisis period will be assessed.

\section{The Emergence of the 2008 Global Financial Crisis}

The problem, which emerged in mortgage-backed securities in the housing market in the USA in September 2007, dispersed rapidly to the banking sector and negatively affected the real sector by penetrating into Europe. A significant contraction was experienced in the world trade since all developed and developing countries were influenced by the crisis. The most typical feature of this crisis that distinct it from other crises is that it emerged outside of developing countries and influenced all countries, rather than it rendered the structural problems of developing countries unsustainable (Kibar, 2008).

The emergence of this crisis, which came to light in September 2008, goes back to the year of 2000. Signs of slowdown in the world economy were observed near the end of 2000, and central banks of the USA, Europe and Japan decided to decrease interest rates by implementing expansionist monetary policies in order to change this economic climate which was showing signs of an economy of recession. This situation caused banks to borrow short-term at low interest rates and lend long-term, due to the ample liquidity in financial markets (Parasiz, 2009a). Especially since these loans were for housing, property prices suddenly started to increase. Banks started to diversify loans and rendered loan conditions highly flexible in order to increase the demand for housing. However, they did not consider in this process that loan-creditors with low income would have trouble in paying back (TCMB, 2008; Parasiz, 2009b). This is a consequence of the irregularity brought about by the liberalization of capital movements. The regulations prescribed for banks have become inadequate due to the high velocity of the change in the financial system. Therefore, financial instruments ruling out the existing rules have rapidly been developed. These developments have caused the volume of the financial sector to increase many times more than that of the real sector, and therefore, there emerged a gulf between the value of the asset-backed security and asset prices (Eğilmez, 2008).

The investors' increased tendency to invest in high-profit and high-risk assets instead of long-term and low-interest financial instruments constituted the infrastructure of this process. The most popular of them was mortgage-backed securities. These securities' lack of a liquid secondary market and their distance from the inspection mechanism prevented a risk-based pricing understanding (Saral, 2009). In other words, a value difference, which is not reflecting the reality and is called "bubble", has emerged between the values of goods and services in the real market and their virtual values in virtual markets where they are exchanged as securities. While this value difference between two markets is not a problem when it is a reasonable difference; as this difference increases, on the other hand, serious value losses occur. Later on, sudden decreases observed in virtual value rises, which are in the nature of bubble (Eğilmez, 2010). On the other hand, the excess liquidity in the market has increased the inflationist tendencies after 2004, and therefore, the FED started to increase interest rates. This caused the demand for housing to decline by affecting the mortgage market beginning from 2005. Therefore, house prices started to fall due to the decrease in demand. In addition, problems in the repayment of housing loans caused financing companies that granted mortgage-backed loans to make losses (Akgüç, 2009).

With the fall of prices of mortgage-backed securities due to the fall of house prices, investors started to prefer low-profit and low-risk government bonds. This preference caused the demand for asset-backed securities to decline and caused their prices to fall further. Then, financial organizations holding mortgage-backed securities had troubles in providing collateral to cover their short-term liquid needs and faced with the threat of bankruptcy. The real important development was the diffusion of the financing problem from the housing market to other financial markets. The feared has happened in the end, and the covert global financial crisis became visible as Lehman Brothers, which had been one of strong investment banks in the USA, filed for bankruptcy in September 2008. This situation, by creating a problem of confidence, increased the attempts in financial markets to turn to cash. Increased perception of risk not only increased the risk premium but also tightened the loan conditions due to the decreases in the desire for credit granting (TCMB, 2008). This illness that became global rapidly spread into the entire world and the world economy started to contract by entering into a serious recession. Countries that have been affected most by the crisis 
were those having bad debt dynamics, high need for foreign resources and weak budget structures. In addition, the bottlenecks that the firms who were suffering credit inconsistency experienced have paved the way for the contraction of supply and lowering of targets. On the other hand, increased pessimism about the future on the demand side has increased the speed of the crisis.

\section{The Monetary Policy Strategies Pursued by Central Banks against the Global Crisis and Their Effectiveness}

The assumption, known as "Phillips Curve analysis", in the 1970s that there exists a trade off between the unemployment rate and inflation collapsed with the concept of stagflation in which both unemployment and high inflation occur simultaneously. When considered the damage that inflation causes to the economy, the primary economic target of world economies has become price stability. Central banks often pursued different monetary policy strategies in order to achieve price stability. Most common of them are exchange rate targeting, monetary targeting and inflation targeting.

In exchange rate targeting, the value of a country's national currency is pegged to the currency of a strong country in order to decrease inflation and control inflationist expectations (Mishkin, 1999). By targeting exchange rate, prices of foreign trade goods are pegged to the prices of anchor countries. This way, it is tried to break the rigidity of prices and wages in goods that are not traded internationally and to adapt inflation expectations to the inflation of the anchor country. It is targeted with this practice to control the inflation by bringing it closer to the level of inflation in the anchor country. Monetary strategies based on exchange rate anchor can be seen in practice in the forms of soft exchange-rate peg or hard exchange-rate peg (Mishkin and Savastano, 2000). It is not possible in this strategy to sterilize the effects of monetary operations. In other words, the size of the monetary base is limited to the monetary policy and capital flow of the anchor country (Barışık, 2001). Moreover, the exchange rate anchor fixes or limits the prices of goods and services that are exchanged internationally and constitutes an automatic rule for the monetary policy. The elasticity to implement monetary policy according to the requirements of the domestic and international conjuncture ceases to exist with this practice. (Petursson, 2000). On the other hand, uncertainty and risk about the foreign trade decrease since the rate of increase of the exchange rate is already known. Moreover, the inflation rate that is expected to fall through exchange rate targeting may become unsuccessful due to the stagnancy in pricing and expectations of devaluation may rise. More importantly, in the case of a devaluation, the debt burden of the public and private sectors to repay their short-term foreign-exchange-denominated liabilities might increase. This situation paves the way for the emergence of financial crises by making liquidity management difficult (Obstfeld and Rogoff, 1995). Since, in the exchange rate targeting, the size of the monetary base wholly (or partially) depends on the inflow of foreign assets in the case of financial crisis, the central bank ceases to have any control on money supply and interest rates. In this respect, the inability of the central bank to intervene in economic developments accelerates the emergence of the crisis and paves the way for it to deepen (Seyidoğlu, 2003). This situation reveals the conclusion that the exchange rate targeting is generally not resistant to financial crises.

Monetary targeting strategy, was firstly proposed by Milton Friedman, who pioneered the group known as monetarists and suggested that monetary aggregates should be regulated (Yay, 2006) This strategy proposes monetary aggregates to be targeted. Targeted monetary aggregates might be in the forms of monetary base, different money reserves and credit aggregates (Cukierman,1996). The stability of the money demand is very important in monetary targeting. The stability of money demand is jeopardized in two situations. The first one emerges if money demand faces big and unanticipated shocks. The second situation emerges if the target monetary aggregate is a board definition of monetary aggregate on which the central bank's control is weak. In the second situation, the correlation between the target aggregate and the target variable weakens and the monetary targeting strategy loses its effectiveness. The experienced financial liberalization caused money substitute to increase and this rendered money demand unstable. The unstable demand has reduced the correlation between monetary aggregates and inflation in the short-run. This can also be observed in the late transformation of high money growth rates into inflation (Mishkin, 1999). In many countries that implemented structural change and financial liberalization programs after the 1980s; the stability of the velocity of money disappeared, the money demand became unstable due to the emergence of new financial instruments and the rapid growth of the financial sector, and therefore, this strategy became unsuccessful since it became difficult for monetary aggregates to be selected as intermediate targets (Oktar, 1998a). About the success of monetary targeting in practice, it has been observed in the USA, Canada and the UK that monetary targeting could not become successful in controlling inflation. This result has been obtained since monetary targeting could not be seriously monitored, and the relationship between the target variables such as inflation or nominal income and monetary aggregates was unstable. On the other hand, Germany and Switzerland successfully pursued the monetary targeting strategy. This result has been obtained since they paid attention to the inflation target rather than monetary targets and loosely implemented the strategy by sometimes disregarding monetary targets (Mishkin, 1999;Bernanke et al, 1999; Clarida and Gertler, 1996). 
Another monetary policy strategy is inflation targeting. Inflation targeting is the announcement of a numerical inflation target or a target interval to be achieved in a certain time period by the central bank with or without the government, and implementing monetary policy applications accordingly (Bernanke and Mishkin, 1997). Inflation targeting has emerged as an outcome of a movement consisted of people who called themselves as New Neoclassical Synthesizers and preferred policies achieving price stability and minimizing output gap. (Büyükakın, 2007). This understanding both removes the dynamic time inconsistency problem and aligns expectations with the inflation target (Goodfriend, 2002). In this framework, as short-term interest rates have become a political instrument, the monetary policy is considered to be an internal process that systematically responds to economic developments, rather than being an external process. This strategy, hence, includes the adoption of price stability as the main target in ensuring macroeconomic stability as well as the policy elasticity for ensuring stability in the production side (Oktar, 1998b).

It is notable feature that inflation targeting includes "policy elasticity", since the other monetary policy strategies (exchange rate targeting and monetary targeting) include a regulated (inelastic) monetary policy that is implemented after determining monetary conditions in advance. Rule-based policy is based on the rule -known as Taylor rule- that the central bank defines a monetary policy rule and takes decisions according to this rule. It is accepted that this perspective also underlies the inflation-targeting regime (Eroğlu, 2008). In discretionary policies, on the other hand, policy decisions should be made by monetary authorities according to internal and external conditions. McCallum (2001) considers the approach of inflation targeting to be a policy designed to achieve the targeted inflation rate, that is, a policy based on rule. In this perspective, determination and announcement of a clear inflation target by central banks in inflation targeting implies that the implementation is rule-based (Yay, 2006). It is should be noted that, within the framework of this strategy, defining lower and upper limits for the desired inflation rate as an uncertainty range and allowing policymakers to decrease the effects of the supply and demand shocks faced in the fluctuations in the economic conjuncture render flexible the above-mentioned rule-based policy. Such a practice provides central banks with a room for maneuvering where they can consider variables such as employment and exchange rate or they can behave discretionary. This feature, which can be called as "limited discretion", renders inflation targeting a monetary policy strategy based on both rules and discretionary practices, and gives the opportunity to be oriented with not only domestic but also international developments (Bernanke and Mishkin, 1997). On the other hand, the floating exchange rate regime increases the efficiency of monetary policy practices against the possible cyclical fluctuations in an outward-oriented economy. In this respect, in countries implementing inflation targeting, floating exchange rate regime is preferred and mid-term interest rates are used as policy instruments (Öztürk, 2009).

\section{The CBRT's Liquidity Management}

There exists a close link between central banks' liquidity management and monetary policy strategies they follow. In exchange rate targeting, liquidity management is executed with the fixed interest rate criterion and the change in the monetary base is based on net inflow of foreign assets. On the other hand, the monetary aggregate selected as the target becomes decisive in monetary targeting. In liquidity management, countries adopted the floating exchange rate regime exhibited better performances in the recent 2008 Global Crisis than those adopted the fixed exchange rate regime did. This performance superiority stems from the fact that the inflation targeting regime provides a considerable amount of elasticities against supply and demand shocks under the floating exchange rate policy compared to fixed interest rate regimes (Başc1, 2008). The first of these elasticities is the possibility to use short-term interest rates as a policy instrument according to the conditions as long as the inflation target is not abandoned. The second is; the shock-decreasing effect of growth dynamics. At times of capital outflows, the rise of the exchange rate (decline in the value of the national money) will decrease the demand contraction by having a positive influence on exports. In other words, the decrease in exports that is a consequence of the demand contraction will be limited. The third is the limiting effect on inflation volatility. Here, the inflation caused through the exchange rate due to capital outflows can be limited by increasing short-term interest rates. The last one is the easiness to supply the liquidity need of the banking sector. Since central banks get the opportunity to pursue the loosened monetary policy, which is a requirement of the floating exchange rate regime, against the new conditions brought about by global crisis, they became relatively successful in their monetary policy practices. In this respect, the volatility of the macroeconomic variables in countries implementing loosened monetary policies thanks to the floating exchange rate regime has been lower than that of countries having to implement rule-based monetary policies that are an inevitable consequence of the fixed exchange rate regime (TCMB, 2008). Therefore, countries implementing floating exchange rate regime have been less affected by the negative climate of the crisis, since this regime is of a "shock-absorbing character" (Berkmen, et al, 2009).

With the emergence of the 2008 Financial Crisis, it was a common opinion that the effects of the crisis would separate the developed and developing countries. However, the separation occurred between countries implementing fixed and floating exchange rate regimes. Especially in the pre-2007 period when liquidity opportunities were high, central banks of countries implementing fixed exchange rate regime purchased inflowing foreign currency as a requirement of the pursued exchange rate regime and -consequently- the amount of national money in the market increased. Hence, foreign exchange reserves of these countries' central banks have increased and the money supply was expanded with 
the increased liquidity. The increased liquidity in markets naturally decreased interest rates and both investment demand and production demand increased. This situation accelerated growth on the one hand, but brought about high inflation on the other (Yllmaz, 2008).

On the other hand, in this period when ample liquidity was experienced in international markets, the developments in the economies of countries implementing floating exchange rate regime were different from those in the economies implementing fixed exchange rate regime. In the floating exchange rate regime, the domestic demand could be controlled through the controlled interest rate policy. In this framework, while inflation rates were around 5\% in the countries whose currencies are fixed to Euro in the beginning of 2007, they rose to $14 \%$ in the middle of 2008 . Similarly, in Middle Eastern countries whose currencies are fixed to the US Dollar, inflation rates - on the average -quadrupled in the same time period. In addition, inflation rates also increased in countries implementing floating exchange rate regime, but the rate of increase rose from an average of 3\% to $7 \%$ (Y1lmaz, 2008). A similar difference was also observed in credit contraction. It is expected during a possible credit contraction that the cost of borrowing for all firms and the government increases, and inflation and growth rates rapidly fall due to the decline in the aggregate demand (Başc1, 2008). Developments were as expected; central banks of the countries implementing fixed exchange rate regime expeditiously removed domestic currency from circulation in order to maintain the exchange rate or keep it within a certain band against the capital outflow. This caused the risk premium to rise by rapidly squandering foreign exchange reserves. In this respect, the rapid contraction of the money supply led to a sharp fall of inflation, and on the other hand, the excessive rise of interest rates brought about a sharp fall in economic activity. However, under the same circumstances, a rapid contraction in the money supply was not experienced in the floating exchange rate regime, but, on the contrary, loose monetary policy could be implemented; since it is necessary in this regime to intervene in the exchange rate against the capital outflow or since limited intervention is not made in order to prevent unhealthy price formation in the currency market. This situation led not only to a slower decline of inflation in spite of the loose monetary policy (due to the recession economy) but also to a slower contraction in the volume of economic activity since interest rates did not increase.

Countries have taken serious measures in order to protect themselves or to escape from the negative effects of the 2008 Financial Crisis. The most prominent of them are: the USA where the crisis first emerged and European countries that have been affected most. These countries not only reduced interest rates to the lowest possible level but also started to implement nonconventional monetary policy methods. Japan implemented "quantitative easing" against the risk of deflation, the USA implemented "credit easing" due to the problems in credit and money markets, "enhanced credit support" was implemented in Europe due to the liquidity need of the banking sector, and "asset purchase program" was implemented in England in the form of direct asset purchasing from banks in order for financial markets to achieve and maintain stability (Özdemir, 2009). As was the case in other countries, the 2008 Financial Crisis had effect on the Turkish economy and policymakers had to take several measures both in fiscal policy and monetary policy practices. The CBRT has taken the following measures in order to decrease the cost of the problems experienced in international credit markets and the global economy to the Turkish economy and to maintain stability in the financial system (Yilmaz, 2009):

1-The Central Bank, without being inconsistent with price stability, pursued a controlled but fast interest-reduction policy.

2- The Central Bank resumed its intermediation role in the Foreign Exchange and Banknotes Market FX Deposit Market on October 9, 2008. Banks' transaction limits in this market were doubled up to a sizable 10.8 billion US dollars on October 24 by considering their balance sheet sizes.

3- Foreign exchange buying and selling auctions were held between October 16, 2008 and April 3, 2009 in order to consolidate banks' foreign exchange liquidity conditions, and a total of 900 million US dollars were sold in 18 auctions.

4- Beginning from November 21, 2008, the maturity of deposits denominated in the US dollar and Euro that banks could buy in the foreign exchange deposit market was first lengthened from one week to one month and then to three months. The loan interest rates that had been defined as $10 \%$ in this market were first reduced to $7 \%$ for the US Dollar and $9 \%$ for Euro, and then to $5.5 \%$ for the US Dollar and $6.5 \%$ for Euro.

5 - Another regulation was made in foreign exchange required reserve ratios. The CBRT reduced the foreign exchange required reserve ratio from $11 \%$ to $9 \%$ on December 5, 2008. In addition, the interest payments on foreign exchange reserve requirements were cancelled and the interest rate on Turkish Lira reserve requirements was increased.

6- On December 5, 2008, the Bank raised pre- and post-shipment export rediscount credit limits by 500 million US dollars to 1 billion US dollars, and then to 2.5 billion US dollars. 
7- On January 29, 2009, Liquidity Support Credits were rendered available to banks, in cases of emergency, as advance payments, with one-month maturities, for a maximum period of one year, limited to the amount twice as much as the equity capital of the applying bank.

In addition to these, the CBRT kept additional measures package on hand just in case. One of them was the bringing forward of the technical interest rate cut for TL. Depending on the course of the liquidity squeeze, extension of the maturity of repo funding and direct purchases of government securities were among the measures considered to be taken. It was also considered to reduce the YTL-denominated required reserves to a limited extent, in case the increase in liquidity squeeze becomes permanent and other measures are not sufficient. In addition, it was projected, in the additional measures package for foreign currencies, to restart foreign exchange selling auctions in a way in line with the floating exchange rate regime or to directly intervene in the foreign exchange market and to increase banks' transaction limits in the foreign exchange and banknotes markets, extension of loan maturities in the foreign exchange deposit market and to decrease lending interest rates. A limited decrease in foreign exchange required reserve ratios was stated among the measures to be taken for the regulation of foreign exchange liquidity.

In the light of the above mentioned measures; as it has been the case in the US, Japanese and European banking systems, the CBRT was not obliged to use nonconventional instruments in monetary policy implementations. During the crisis, regulations made in policy interest rates sufficed to give the desired reactions. It became possible to influence the money supply commensurately. In this respect, the fact that the lowest annual inflation outturn (5.08\%, as of October 2009, (www.tcmb.gov.tr)) in Turkey in the crisis period did not evoke a deflation risk points to the unnecessity of monetary supply increase. Besides, the crisis experienced by Turkey in 2001 caused the CBRT to act with more deliberation in liquidity management during the 2008 crisis.

The CBRT was able to keep economic activity under control through the increase in the value of the domestic currency by increasing interest rates in periods of ample liquidity (2006 Financial Turbulence). On the other hand, loosening interest rates in a controlled way and decrease in the value of currency have limited the size of contraction in economic activity (2008 Financial Crisis). Although some people think that this situation is based on the monetary authorities' decision to adopt a policy called high interest-low exchange rate (Yeldan 2008), the CBRT explains this with the presence of significant differences between the two periods in terms of economic situation and the sources of shocks (Y1lmaz, 2009). Contrary to the strong demand conditions in 2006, in the 2008 Crisis, weak pressure of the internal and external demand on inflation, worsened credit conditions, and reductions in interest rates that were not associated with inflation due to the decrease in the transitivity from the exchange rate to prices confirm this difference.

On the other hand, incorporation of inflation targeting with the floating exchange rate regime has improved economic units' protection motivations against risks and derivative markets (options, forward, futures, currency swaps). Especially the bitter experience caused by the currency risk based on short position in the 2001 crisis rendered inevitable the consideration of currency risk in the 2008 crisis. In addition, inflation targeting necessitates the stabilization of financial markets through the intermediation of institutions responsible for financial inspection and regulation. The CBRT's role as the "final crediting authority" has served as an insurance to avoid a liquidity-based financial crisis. Both the advantage of floating exchange rate regime and the legal regulations made in financial markets in the past have improved the CBRT's liquidity management skills against the global financial crisis and decreased the necessity to intervene in the foreign exchange market (Işık and Duman, 2008). In conclusion, the CBRT, as a requirement of the economic situation in the crisis period, found the possibility to pursue a flexible liquidity management, which was appropriate to the nature of inflation targeting and in line with the main target of price stability. This strengthened the CBRT's hand to relief the effects of the global crisis through proper and timely buying and selling activities in foreign exchange markets in order to prevent markets from speculative attacks, along with the main instrument of short-term interest rates. Unlike many other countries, these monetary policy attempts of the CBRT, with the influence of the measures successfully taken in the fields of fiscal discipline and the banking sector after the 2001 crisis, have become successful in preventing financial threats. In addition, as an outcome of the monetary policy measures taken during the crisis, if the peak values of the Gross Domestic Product (GDP) prior to the 2001 and 2008 crises (for the 2001 crisis 2000/4 ${ }^{\text {th }}$ Quarter, for the 2008 crisis 2008/1 ${ }^{\text {st }}$ Quarter) are taken as 100; it is observed that the GDP peaked faster and fell down faster in the 2001 crisis, and it peaked and fell down slower in the 2008 crisis (Graph:1). This demonstrates that the CBRT displayed a better performance in the 2008 crisis compared to the 2001 crisis, depending on the lower extent of growth volatility. However, contrary to the well-defined structural reform priorities in the 2001 crisis, Turkey's inability in the 2008 crisis to carry out necessary reforms of different kind (measures to increase investments based on domestic savings) and her inability to establish an atmosphere of confidence that would increase private investments increased the cost of the crisis (Adalet and Altuğ, 2010). The refusal of the IMF's financial support in the peak period of the crisis has become a factor that delayed the recovery from the crisis and the reestablishment of confidence. 


\section{Conclusion}

The most frightening aspect of the crisis in the financial sector, almost all economic units' tendency to turn to cash due to loss of confidence. This naturally increases the liquidity demand. Therefore, a good liquidity management becomes important to avoid the destructive effect of the crisis or to recover from the crisis with the lowest cost. This depends on the policymakers' crisis management skills as well as monetary policy strategies that allow most freedom to regulate liquidity. The monetary policy strategy that allows most freedom to regulate liquidity (loosened monetary policy practices) is the inflation targeting strategy. The inflation targeting strategy delivers a performance that is more resistant to national or global economic shocks and is able to limit the deviations in macro variables more.

Within the framework of the 2008 Financial Crisis, the CBRT pursued a cautious monetary policy by considering the possible fluctuations in financial markets in advance. In this respect, the CBRT followed a controlled but fast interest-reduction policy so as not to contradict with price stability. In addition, it intervened in the foreign exchange market through proper and timely buying and selling activities in order to prevent the speculative attacks in the price formation. Moreover, the loan interest rates and required reserve ratios for foreign currency were properly reduced. Regulations that increased maturities and amounts in the assurance of banks' equity capitals in cases of emergency were made. In case the measures taken would be inadequate, direct purchases of government securities and reducing the YTL-denominated required reserves to a limited extent were the other measures considered. These practices lead to the conclusion that the CBRT was successful in liquidity management since a serious liquidity squeeze and a serious crisis in the banking sector were not experienced.

\section{References}

Adalet, M.\& Altuğ, S. (2010). 2001 ve 2008 Krizlerinin Karşılaştırılması, Ekonomik Araştırmalar Forumu (EAF), TÜSİAD- Koç Üniversitesi Politika Notu 10-08, Nisan, ss.1-5

Akgüç, Ö. (2009). Kriz Nedeni ve Çıkış Yolları, Muhasebe ve Finansman Dergisi, Sayı:42, Nisan, ss.6-11.

Barışı, S. (2001). Para Kurulu Sistemi, Üstünlükleri ve Zayıf Yönleri, Gazi Üni. İ̈BF Dergisi, Sayı: 2, ss.51-68.

Başcı, E. (2008). Küresel Mali Kriz ve Para Politikası Konferansı, http://www.ku.edu.tr/ku/images/EAF/desifre _17122008.pdf (01.04.2010), ss.1-44

Berkmen, P. et al. (2009). The Global Financial Crisis: Explaining Cross-Country Differences in the Output Impact.IMF Working Paper, WP/09/280, pp. 1-19.

Bernanke, B.S. \& Mishkin, F.S. (1997). Inflation Targeting: A New Framework for Monetary Policy? NBER Working Paper, No: 5893, http://www2.gsb.columbia. edu/faculty/fmishkin/PDFpapers/w5893.pdf (10.04.2007), pp.1-28.

Bernanke, B. et al. (1999). Inflation Targeting:Lessons From The International Experience, New Jersey: Princeton University Press.

Büyükakın, T. (2007). Yeni Keynesyen İktisat mı, Yeni Neo-Klasik Sentez mi?, Kocaeli Üni. Sosyal Bilimler Enstitüsü Dergisi, Y11:13, Say1:1, ss.22-36

Clarida, R. \& Gertler M. (1996). How The Bundesbank Conducts Monetary Policy, NBER Working Paper, No.5581 http://www.nber.org/papers/w5581.pdf (1.1.2008), pp.1-50

Cukierman, A. (1996). Targeting Monetary Aggregates and Inflation in Europe, http://arno.uvt.nl/show.cgi?fid=3346 (10.10.2010), pp.1-27

Eğilmez, M. (2008). Küresel Krizin Nedenleri, Radikal Gazetesi (23.09.2008).

Eğilmez, M. (2010). Küresel Finans Krizi, 6.Bask1, İstanbul Remzi Kitabevi.

Eroğlu, N.(2008). Türkiye'de Parasal Kesim ve Merkez Bankası İslemlerinin Analizi, 2. Baskı, İstanbul: Der Yayınları.

Goodfriend, M.(2002). Monetary Policy in the New Neoclassical Synthesis: A Primer, International Finance, 5(2),http://www.richmondfed.orgpublications/economicresearch/economic_quarterly/pdfs/summer2004/goodfriend. pdf (20.08.2008), pp.21-45.

Işık, S. \& Duman, K. (2008). Enflasyon Hedeflemesi ve Dalgalı Döviz Kuru: Bazı Ülke Deneyimleri. Akdeniz Üni. İ.I.B.F. Dergisi, (15), ss.50-86.

Kibar, A. (2008). Küresel Mali Kriz ve Para Politikası Konferansl, http://www.ku.edu.tr/ku/ images/EAF/desifre _17122008.pdf (01.04.2010), ss.1-44.

McCallum, B.T. (2001). Inflation Targeting and The Liquidity Trap, NBER Working Paper, No.8225, April 2001, http://www.nber.org/papers/W8225 (10.05.2007), pp. 1-52. 
Mishkin, F.S. (1999). International Experiences With Different Monetary Policy Regimes, NBER Working Paper, No. 6965, http://papers.nber.org/papers/w6965.pdf (10.05.2007), pp.1-46.

Mishkin, F.S. \& Savastano, M. (2000). Monetary Strategies for Latin America, NBER Working Paper Series, No.7617, March 2000, http://www.nber. org/papers /w7617.pdf (1.01.2008), pp.1-67.

Obstfeld, M., Rogoff, K.(1995). The Mirage of Fixed Exchange Rates, NBER Working Paper Series, No.5191, http://www.nber.org/papers/ w5191.v5.pdf (20.01.2008), pp.1-35.

Oktar, S. (1998a). Para Politikasının Güvenilirliği ve Güvenilirliğinin Sağlanmasında Enflasyon Hedeflemesi Yaklaşımı, Banka ve Ekonomik Yorumlar Dergisi, Y.35, S.2, Şubat, ss.1-17.

Oktar, S. (1998b). Enflasyon Hedeflemesi, Birinci Basım, İstanbul: Bilim Teknik Yayınevi.

Özdemir, A.(2009). Para Politikası, Parasal Büyüklükler ve Küresel Mali Kriz Sonrası Gelişmeler.TCMB, Araştırmalar ve Para Politikası Genel Müdürlüğ̈̈, Çalışma Tebliği, No:09/5.

Öztürk, S. (2009). Enflasyon Hedeflemesi Yaklaşımı: Gelişmiş ve Gelişmekte Olan Ülkelerin Karsılaştırmalı Analizi, Celal Bayar Üni. İ̈F Yönetim ve Ekonomi Dergisi, Cilt:16, Sayı:1, ss.191-205.

Parasız, İ.(2009 a).Küresel Kriz, 1.Bask1, Bursa: Ezgi Kitabevi.

Parası, İ.(2009 b). Para Banka ve Finansal Piyasalar, 9. Bask1, Bursa: Ezgi Kitabevi.

Petursson, T.G.(2000). Exchance Rate or Inflation Targeting in Monetary Policy?, Money Bulletin, 2000/1, http://www.sedlabanki.is/uploads/files/mb001_6.pdf (10.05.2007), pp. 36-45.

Saral, T.(2009). Küresel Kriz Üzerine Düşünceler ve Öneriler, Maliye Finans Yazıları Dergisi, Yı1:23, Sayı:83, ss. 9-24

Seyidoğlu, H.(2003). Uluslararası Mali Krizler, IMF Politikaları, Az Gelişmiş Ülkeler, Türkiye ve Dönüşüm Ekonomileri, Doğuş Üniversitesi Dergisi, Cilt.4, No.2, ss. 141-156.

TCMB (2008). Uluslararası Gelişmeler ve Türkiye Ekonomisine Etkileri, İstanbul Ticaret Odası Sunumu, TCMB, (Aralık), ss.1-47.

Yay, G.G. (2006). Para Politikası Stratejileri ve Enflasyon Hedeflemesi. İktisat Dergisi, Şubat-Mart, Sayı: 470-471, ss.3-17.

Yeldan, E.(2008). 2009'da Para Politikası Nereye?http://www.bilkent.edu.tr/ yeldane/ Yeldan194_24Ara08.pdf (09.02.2010).

Yılmaz, D.(2008). Küresel Mali Kriz ve Türkiye Ekonomisine Etkileri; Nasıl Başladı, Hangi Aşamadayız. Küresel Bunalım ve Türkiye Ekonomisi Konulu Çalıştayda Yaptı̆̆ Konuşma, Ankara: TCMB (Aralık), www.tcmb.gov.tr (27.12.2008), ss. 1-11.

Yılmaz, D. (2009). 77. Olağan Genel Kurul Toplantısı Açıllş̧ Konuşması, TCMB, Ankara, ss.1-23.http://www.tcmb.gov.tr (August 7, 2010).

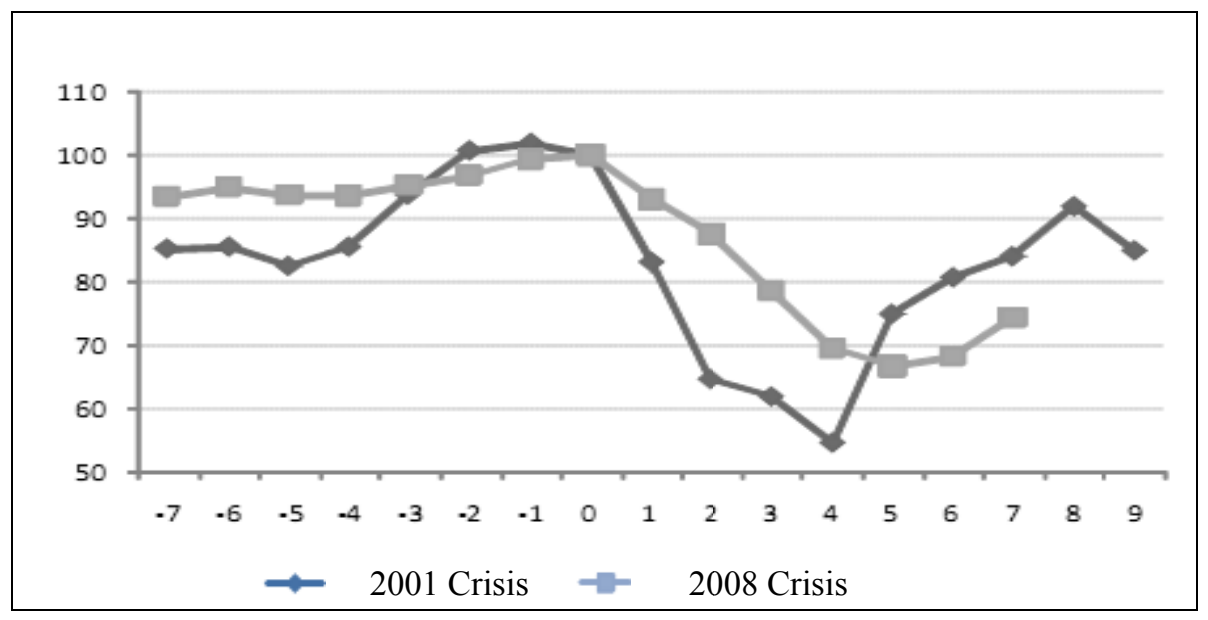

Graph 1. GDP values -seasonality excluded- (Peak Prior to the Crisis=100)

Source: OECD; quoted by: Adalet and Altuğ 2010:1 